\title{
PENGARUH PENGENDALIAN INTERNAL DAN KOMITMEN ORGANISASI TERHADAP PENCEGAHAN FRAUD PENGADAAN BARANG (Studi Empiris pada Rumah Sakit Pemerintah di Kota Ambon)
}

\author{
Senda Y. Leatemia \\ Jurusan Akuntansi, Fakultas Ekonomi dan Bisnis Universitas Pattimura, Universitas Pattimura Ambon \\ e-mail: senda.leatemia@feb.unpatti.ac.id \\ Nickita F. Febryanti \\ Jurusan Akuntansi, Fakultas Ekonomi dan Bisnis Universitas Pattimura, Universitas Pattimura Ambon
}

\begin{abstract}
ABSTRAK
Penelitian ini bertujuan adalah untuk menguji pengaruh pengendalian internal dan komitmen organisasi terhadap pencegahan fraud pengadaan barang pada rumah sakit pemerintah Kota Ambon. Penelitian ini menggunakan pendekatan kuantitatif. Objek yang diteliti adalah karyawan bagian keuangan, bagian perencanaan dan bagian logistik (pengadaan barang). Teknik pengumpulan data dilakukan menggunakan kuesioner dengan jumlah sampel penelitian sebanyak 50 responden. Metode analisis yang digunakan adalah teknik analisis regresi linear berganda. Hasil penelitan menunjukkan bahwa (1) pengendalian internal berpengaruh positif terhadap pencegahan fraud pengadaan barang, (2) komitmen organisasi berpengaruh positif terhadap pencegahan fraud pengadaan barang.
\end{abstract}

Kata Kunci: Pengendalian Internal, Komitmen Organisasi, Pencegahan Fraud Pengadaan Barang.

\begin{abstract}
This study aims to examine the effect of internal control and organizational commitment to the prevention of procurement fraud in state hospitals in Ambon City. This study uses a quantitative approach. Subjects studied were employees in the department of finance, planning and logistics (procurement of goods). Data collection techniques were carried out using a questionnaire with a total sample of 50 respondents. The analytical method used is multiple linear regression analysis techniques. Research results show that (1) internal control has a positive effect on the prevention of procurement fraud, (2) organizational commitment has a positive effect on the prevention of procurement fraud.
\end{abstract}

Keywords: Internal Control, Organizational Commitment, Prevention of Procurement Fraud

\section{PENDAHULUAN}

Dunia medis saat ini mengalami perkembangan yang begitu pesat terutama pada bidang pelayanan. Kebijakan pemerintah tentang pendirian rumah sakit, puskemas dan semacamnya sudah merambah ke berbagai penjuru daerah. Bukan hanya kuantitas saja yang menjadi sorotan masyarakat tetapi juga kualitas dari pelayanan kesehatan rumah sakit, menjadi prioritas utama yang dibutuhkan oleh masyarakat.

Rumah sakit sebagai entitas pelayanan umum dituntut untuk tetap bertahan dan memperlihatkan kinerjanya dengan baik, dimana kondisi krisis global memberikan dampak pada hampir seluruh sektor perekonomian, termasuk rumah sakit. Pengelolaan rumah sakit yang baik tentunya akan memberikan acuan ataupun gambaran bagaimana rumah sakit terkelola secara transparan, mandiri, akuntabel, bertanggungjawab dan wajar sehingga kinerja keuangan pada rumah sakit dapat dicapai sesuai dengan visi dan misi rumah sakit yang telah ditentukan sebelumnya, namun demikian harapan di atas belum sepenuhnya dapat dirasakan.

Beberapa hal yang belum tercapai dikarenakan belum memadainya instrumen organisasi untuk menciptakan pengendalian internal yang efektif dan komitmen organisasi yang baik dari para pengelola rumah sakit. Akibatnya muncul berbagai penyimpangan, penyelewengan, penyelundupan, dan korupsi.

Komisi Pemberantasan Korupsi (KPK) mengungkapkan pengadaan alat kesehatan (alkes) menjadi sektor yang paling banyak di korupsi di antara 5 jenis tindak pidana korupsi di bidang kesehatan. Pengadaan alkes di daerah kerap kali tak tepat sasaran dan penggunaan, serta fungsi pengawasan Kemenkes terhadap pengadaan alkes masih kurang. Salah satu potensi kecurangan terdapat pada proses perencanaan pengadaan obat. (pikiran rakyat.com) 
Tingginya intensitas praktik kecurangan, penipuan dan penggelapan yang terjadi pada suatu institusi publik maupun privat, dengan segala modusnya, dari yang sederhana sampai yang sangat canggih dan rumit, seharusnya menyadarkan semua pihak untuk membangun komitmen terhadap penerapan tata kelola yang baik secara konsisten dan meluas pada semua lapisan karena tanpa adanya kesadaran dan komitmen akan mengakibatkan tidak tercapainya kinerja keuangan yang baik pada rumah sakit (Hermiyetti, 2010).

Tindakan kecurangan biasanya dilakukan oleh seseorang yang mendapat tekanan atau dorongan untuk melakukan kecurangan karena adanya peluang meraup keuntungan yang lebih besar atau sebagai pemenuhan kebutuhan yang mendesak atau yang harus segera terpenuhi, tanpa memikirkan resiko yang akan di hadapi. Peluang inilah yang menyebabkan resiko terjadinya fraud semakin besar. Dimana indikasi orang melakukan kecurangan adalah adanya tekanan (pressure), peluang (opportunity), rasionalisasi (rasionalization), kompetensi (competence), dan arogansi (arrogance).

Untuk mengatasi timbulnya kecurangan, audit internal diperlukan keberadaannya di dalam instansi, yang bertugas untuk mengevaluasi suatu sistem dan prosedur yang telah disusun secara benar dan sistematis, telah diimplementasikan secara benar, melalui pengamatan, penelitian, dan pemeriksaan atas pelaksanaan tugas yang telah didelegasikan disetiap unit kerja dalam instansi. Menurut Standar Profesi Audit Internal (2004), evaluasi sistem pengendalian internal harus mencakup:

1. Efektifitas dan efisiensi kegiatan operasi.

2. Keandalan dan integritas informasi.

3. Kepatuhan terhadap peraturan perundang-undangan yang berlaku.

4. Pengamatan aset organisasi.

Salah satu jenis kegiatan yang dilakukan oleh audit internal adalah pencegahan dan pendeteksian kecurangan. Tipe kejadian ini merupakan aktivitas yang volumenya cukup tinggi dan secara umum dihadapi oleh audit internal. Kecurangan adalah suatu bentuk kejahatan. Ada banyak jenis kecurangan, diantaranya korupsi, penggelapan, pencurian dan lainnya.

Lemahnya satuan pengawasan intern di Rumah Sakit karena pejabat yang bertanggung jawab lemah dalam melakukan pengawasan maupun pengendalian kegiatan dan belum sepenuhnya memahami ketentuan dan adanya koordinasi dengan pihak yang terkait, serta komitmen organisasi yang lemah. Oleh sebab itu, suatu instansi atau organisasi harus memiliki sistem pengendalian internal yang efektif, dimana setiap aktivitas-aktivitas yang dilakukan karyawan dalam instansi atau organisasi tersebut mendapatkan pengawasan yang ketat. Dengan adanya pengendalian internal yang efektif diharapkan dapat meminimalisasikan perilaku menyimpang yang merujuk pada tindakan kecurangan (fraud) dalam instansi atau organisasi.

Selain pengendalian internal yang diterapkan sebagai salah satu tindakan preventif dalam mencegah kemungkinan terjadinya fraud, komitmen organisasi juga merupakan salah satu yang dapat meminimalisir terjadinya fraud. Dalam hal ini, komitmen organisasi yaitu suatu sikap atau tingkah laku seseorang kepada organisasi berupa loyalitas dan tercapainya visi, misi, serta tujuan organisasi sangat besar pengaruhnya bagi tindak pencegahan fraud.

Berdasarkan pada latar belakang diatas terdapat permasalahan dalam penelitian ini sebagai berikut:

1. Apakah pengendalian internal berpengaruh signifikan terhadap pencegahan fraud pengadaan barang.

2. Apakah komitmen organisasi berpengaruh signifikan terhadap pencegahan fraud pengadaan barang. berikut:

Berkenaan dengan pokok permasalahan diatas, maka tujuan dari penelitian ini adalah sebagai

1. Untuk menguji pengaruh pengendalian internal terhadap pencegahan fraud pengadaan barang.

Untuk menguji pengaruh komitmen organisasi terhadap pencegahan fraud pengadaan barang.

\section{LANDASAN TEORI}

\section{Pengendalian Internal}

Menurut Mulyadi (2002), pengendalian internal adalah suatu proses yang dijalankan oleh dewan komisaris, manajemen, dan personel lain entitas yang didesain untuk memberikan keyakinan memadai tentang pencapaian tiga golongan tujuan, yaitu keandalan laporan keuangan, efektifitas, dan efisiensi operasi, serta kepatuhan terhadap hukum dan peraturan yang berlaku. Pengendalian internal yang efektif memegang peran penting dalam organisasi untuk meminimalisir terjadinya kecurangan, sehingga dapat menutup peluang terjadinya perilaku menyimpang.

Zulkarnain (2013) mengatakan bahwa sistem pengendalian internal yang efektif merupakan suatu sistem yang terdiri dari kebijakan, prosedur, cara, dan peraturan yang ditetapkan oleh perusahaan agar rencana dan tujuan dapat dicapai dengan baik. Dengan adanya pengendalian internal yang efektif akan menghindarkan terjadinya tindakan-tindakan penyimpangan yang dapat merugikan perusahaan. 


\section{Komitmen Organisasi}

Komitmen organisasi menurut Mowday et al. (1979) mendefinisikan bahwa komitmen organisasi sebagai kekuatan yang bersifat relative dari individu dalam mengidentifikasikan keterlibatan dirinya ke dalam bagian organisasi. Hal ini dapat ditandai dengan tiga hal, yaitu:

1. Penerimaan terhadap nilai-nilai dan tujuan organisasi.

2. Kesiapan dan kesediaan untuk berusaha dengan sungguh-sungguh atas nama organisasi.

3. Keinginan untuk mempertahankan keanggotaan di dalam organisasi.

Meyer dan Allen (1997) mengemukakan tiga komponen tentang komitmen organisasi:

1. Affective Commitment, terjadi apabila karyawan ingin menjadi bagian dari organisasi karena adanya ikatan emosional (emotional attachment) atau merasa mempunyai nilai sama dengan organisasi.

2. Continuance Commitment, yaitu kemauan individu untuk tetap bertahan dalam organisasi karena tidak menemukan pekerjaan lain atau karena rewards ekonomi tertentu.

3. Normative Commitment, timbul dari nilai-nilai karyawan. Karyawan bertahan menjadi anggota organisasi karena ada kesadaran bahwa berkomitmen terhadap organisasi merupakan hal yang memang seharusnya dilakukan.

\section{Pencegahan Fraud Pengadaan Barang}

Pengertian Kecurangan (Fraud) menurut Boynton (1996) kecurangan atau fraud adalah penipuan yang direncanakan misalnya salah saji, menyembunyikan, atau tidak mengungkapkan fakta yang material sehingga merugikan pihak lain. Menurut IAI (2001) dalam Wilopo (2006) menjelaskan kecurangan akuntansi sebagai salah saji yang timbul dari kecurangan dalam pelaporan keuangan yaitu salah saji atau penghilangan secara sengaja jumlah atau pengungkapan dalam laporan keuangan untuk mengelabuhi pemakai laporan keuangan dan salah saji yang timbul dari perlakuan tidak semestinya terhadap aktiva (seringkali disebut dengan penggelapan atau penyalahgunaan) berkaitan dengan pencurian aktiva entitas yang berakibat laporan keuangan tidak disajikan sesuai dengan prinsip akuntansi yang berlaku umum di Indonesia.

The Association of Certified Fraud Examiners (ACFE) mengklasifikasikan kecurangan (fraud) dalam beberapa klasifikasi, dan dikenal dengan istilah "Fraud Tree" yaitu :

1. Kecurangan Laporan Keuangan (Financial Statement Fraud)

Kecurangan laporan keuangan dapat didefinisikan sebagai kecurangan yang dilakukan oleh manajemen dalam bentuk salah saji material laporan keuangan yang merugikan investor dan kreditor. Kecurangan seperti ini disebut kecurangan manajemen (management fraud). Kecurangan ini dapat bersifat financial atau kecurangan non finansial.

2. Penyalahgunaan Aset (Asset Misappropriation)

Penyalahgunaan aset dapat digolongkan ke dalam kecurangan kas dan kecurangan atas persediaan dan aset lainnya, serta pengeluaran pengeluaran biaya secara curang (fraudulent asoursement).

3. Korupsi (Corruption)

Korupsi dalam konteks pembahasan ini adalah korupsi menurut ACFE, bukannya pengertian korupsi menurut UU Pemberantasan TPK di Indonesia. Menurut ACFE, korupsi terbagi ke dalam pertentangan kepentingan (conflict of interest), suap (bribery), pemberian illegal (ilegal gratuity), dan pemerasan (economic extortion).

Korupsi merupakan jenis kecurangan (fraud) yang sering terjadi di sektor pemerintahan. Korupsi merupakan gejala salah pakai dan salah urus dari kekuasaan, demi keuntungan pribadi, salah urus terhadap sumber-sumber kekayaan negara dengan menggunakan wewenang dan kekuatan formal untuk memperkaya diri sendiri. Korupsi dapat membuat pelayanan di rumah sakit menjadi tidak maksimal dikarenakan adanya penyaluran anggaran yang kurang sempurna sehingga baik karyawan maupun pasien ikut dirugikan karena tindakan korupsi yang dilakukan oleh oknum yang berkaitan.

Pengertian Pengadaan Barang menurut Tuanakotta (2007) adalah sektor dimana guna memperoleh barang atau jasa dengan harga yang dapat dipertanggungjawabkan, dengan jumlah dan mutu yang sesuai, serta tepat pada waktunya.

Menurut Pope (2007), pencegahan fraud dalam hal pengadaan barang publik antara lain:

1. Memperkuat kerangka hukum

Peraturan yang selama ini menjadi pedoman pelaksanaan pengadaan barang dan jasa adalah Kepres No. 80 tahun 2003, perlu dikaitkan dengan UU No. 31 tahun 1999 untuk dapat efektif menghalangi tindak pidana korupsi. Persyaratan hukum berikutnya adalah kerangka yang baik dan konsisten prinsip-prinsip dan praktik-praktik dasar pengadaan.

2. Prosedur transparan 
Selain dari kerangka hukum, pertahanan berikutnya melawan fraud adalah prosedur dan praktik yang terbuka dan transparan untuk melaksanakan proses pengadaan barang itu sendiri. Unsur-unsur prosedur transparan adalah sebagai berikut:

a. Menguraikan dengan jelas dan tanpa memihak apa yang akan dibeli.

b. Mengumumkan kesempatan untuk menawar barang.

c. Menyusun kriteria untuk mengambil keputusan pada waktu seleksi.

d. Menerima penawaran dari pemasok yang bertanggung jawab.

e. Audit membandingkan penawaran dan menentukan penawaran yang terbaik menurut peraturan yang telah ditetapkan lebih dahulu.

f. Memberikan kontrak pada penawar yang menang seleksi tanpa mengharuskannya menurunkan harga atau mengadakan perubahan lainnya pada penawarannya.

3. Membuka dokumen tender

Satu kunci untuk mewujudkan transparansi dan sikap tidak memihak adalah pembeli membuka dokumen tender pada waktu dan tempat yang telah ditetapkan, dihadapan semua pengikut tender didepan umum, sehingga setiap orang dapat melihat siapa yang mengajukan penawaran dan dengan harga berapa, dapat mengurangi resiko bahwa tender yang bersifat rahasia itu dibocorkan kepada peserta lain, diabaikan, diubah atau dimanipulasi.

4. Evaluasi penawaran

Evaluasi penawaran adalah langkah yang paling sulit dalam proses pengadaan barang untuk dilaksanakan secara benar dan adil. Bersamaan dengan itu langkah ini adalah salah satu langkah yang paling mudah dimanipulasi jika ada pejabat yang ingin mengarahkan keputusan pemenang pada pemasok tertentu.

5. Melimpahkan wewenang

Prinsip peninjauan ulang dan audit independen sudah diterima luas sebagai cara untuk menyingkapkan kesalahan atau manipulasi dan memperbaikinya. Prinsip ini menduduki tempat yang penting dalam bidang pengadaan barang publik. Namun, prinsip ini juga digunakan oleh beberapa orang untuk menciptakan peluang untuk melakukan korupsi. Khususnya, pelimpahan wewenang untuk menyetujui kontrak.

6. Pemeriksaan dan audit independent

Tinjauan ulang dan audit independen memainkan peran yang sangat penting. Namun, dibeberapa negara tinjauan ulang dan tahap-tahap persetujuan demikian banyak sehingga seluruh proses pengadaan barang publik boleh dikatakan lumpuh. Dibeberapa negara, dalam hal kontrak besar diperlukan waktu lebih dari dua tahun paling tidak untuk menentukan pemenang dari sejak penawaran diajukan.

\section{Hipotesis}

Berdasarkan landasan teori serta model penelitian yang telah dijelaskan diatas, maka hipotesis untuk penelitian ini adalah sebagai berikut:

H1 : Pengendalian internal berpengaruh terhadap pencegahan fraud pengadaan barang.

H2 : Komitmen organisasi berpengaruh terhadap pencegahan fraud pengadaan barang.

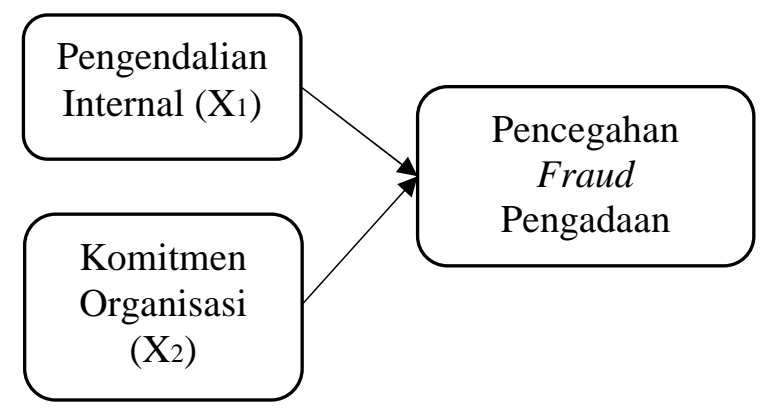

Model Penelitian

\section{METODE PENELITIAN}

\section{Populasi dan Sampel}

Rumah sakit yang menjadi populasi penelitian adalah RSUD Dr. Haulussy dan RSKD Provinsi Maluku. Sampel yang digunakan dalam penelitian ini adalah bagian keuangan, bagian perencanaan, dan 
bagian logistik (pengadaan barang). Sedangkan teknik pengambilan sampel yang digunakan dalam penelitian ini adalah purposive sampling. Kriteria pemilihan sampel dalam penelitian ini ditetapkan sebagai berikut:

1. Karyawan yang memiliki masa kerja sekurang-kurangnya 1 tahun.

2. Karyawan atau staff yang bekerja di bagian keuangan, bagian perencanaan, dan bagian logistik.

\section{Jenis dan Sumber Data}

Data Primer. Dalam penelitian ini, instrument pengumpulan data yang digunakan diantaranya:

1. Wawancara

2. Dokumentasi

3. Kuisioner

Data Sekunder yang digunakan dalam penelitian ini adalah dokumen-dokumen, internet, dan buku literatur.

Variabel Penelitian

Pengendalian Internal

Menurut Mulyadi (2002), pengendalian internal adalah suatu proses yang dijalankan oleh dewan komisaris, manajemen, dan personel lain entitas yang didesain untuk memberikan keyakinan memadai tentang pencapaian tiga golongan tujuan, yaitu keandalan laporan keuangan, efektifitas dan efisiensi operasi, serta kepatuhan terhadap hukum dan peraturan yang berlaku.

Indikator yang digunakan adalah lingkungan pengendalian, penilaian risiko, sistem komunikasi dan informasi akuntansi, aktivitas pengendalian dan pemantauan, yang diukur dengan skala likert.

Komitmen Organisasi

Mayer dan Allen (1997) merumuskan suatu definisi mengenai komitmen dalam berorganisasi sebagai suatu konstruk psikologis yang merupakan karakteristik hubungan anggota organisasi dengan organisasinya dan memiliki implikasi terhadap keputusan individu untuk melanjutkan keanggotaannya dalam berorganisasi.

Indikator yang digunakan adalah komitmen afektif, komitmen berkelanjutan, dan komitmen normative, yang diukur dengan skala likert.

Pencegahan Fraud Pengadaan Barang

Pengertian Kecurangan Akuntansi (Fraud) menurut Boynton (1996) kecurangan atau fraud adalah penipuan yang direncanakan misalnya salah saji, menyembunyikan, atau tidak mengungkapkan fakta yang material sehingga merugikan pihak lain. likert.

Indikator yang digunakan adalah fraud manajemen dan fraud karyawan, yang diukur dengan skala

\section{Metode Pengumpulan Data \\ Studi Lapangan}

Penulis berusaha untuk melakukan penelitian lapangan guna mengumpulkan data-data mengenai pengendalian internal, komitmen organisasi, dan pencegahan fraud pengadaan barang yang dapat diperoleh dari berbagai sumber.

$\underline{\text { Studi Pustaka }}$

Dalam melakukan studi pustaka, penulis berusaha untuk memperoleh gambaran yang lebih jelas, komprehensif, mengenai peraturan perundang-undangan dan peraturan pelaksanaannya, serta referensireferensi lain yang berkaitan dengan masalah penelitian yang diangkat dalam penulisan penelitian ini.

\section{Metode Analisis Data}

Metode analisis data merupakan suatu metode yang digunakan untuk memproses hasil penelitian guna memperoleh suatu kesimpulan. Data tersebut dikumpulkan dan diolah menggunakan alat Uji Statistik Deskriptif dan Uji Hipotesis.

\section{HASIL DAN PEMBAHASAN \\ Deskripsi Objek Penelitian}

Dalam bab ini penulis akan menganalisis data yang telah terkumpul, data yang telah dikumpulkan tersebut berupa hasil jawaban responden untuk mengetahui pengaruh pengendalian internal dan komitmen organisasi terhadap pencegahan fraud pengadaan barang dengan subjeknya yaitu staf bagian keuangan, 
staf bagian perencanaan, dan staf bagian logistik (pengadaan barang) yang mempunyai tugas pokok dan fungsi yang saling berkaitan dengan pengadaan barang pada 2 (dua) rumah sakit pemerintah yang telah terakreditasi di lingkungan Pemerintah Kota Ambon, yaitu RSUD Dr. Haulussy dan RSKD Prov. Maluku (Nania).

\section{Identitas Responden}

Berdasarkan data yang diperoleh dari penyebaran kuesioner menurut jenis kelamin responden, terlihat bahwa responden wanita lebih banyak dibandingkan dengan responden pria. Meskipun secara teoritis tidak terdapat hubungan antara jenis kelamin dengan pencegahan fraud pengadaan barang, namun hal ini perlu diketahui keseimbangan proporsi jenis kelamin. Komposisi responden berdasarkan jenis kelamin adalah sebagai berikut:

Komposisi Jenis Kelamin Responden

\begin{tabular}{|c|c|c|c|}
\hline No. & Jenis Kelamin & $\begin{array}{c}\text { Jumlah } \\
\text { Responden }\end{array}$ & Persentase \\
\hline 1 & Laki-Laki & 12 & 24 \\
\hline 2 & Perempuan & 38 & 76 \\
\hline & Total & 50 & 100 \\
\hline
\end{tabular}

$\underline{\text { Umum Responden }}$

Umur responden pada saat penelitian berlangsung dibedakan menjadi 3 kelompok yaitu 21 tahun sampai dengan 30 tahun, 31 tahun sampai dengan 40 tahun, dan 41 tahun sampai dengan 50 tahun. Komposisi responden berdasarkan umur responden adalah sebagai berikut :

Komposisi Umur Responden

\begin{tabular}{|c|l|c|c|}
\hline No. & $\begin{array}{c}\text { Kelompok } \\
\text { Umur }\end{array}$ & $\begin{array}{c}\text { Jumlah } \\
\text { Responden }\end{array}$ & Persentase \\
\hline 1 & $21-30$ tahun & 17 & 34 \\
\hline 2 & $31-40$ tahun & 23 & 46 \\
\hline 3 & $41-50$ tahun & 10 & 20 \\
\hline & Total & 50 & 100 \\
\hline
\end{tabular}

Pendidikan Terakhir

Tingkat Pendidikan responden dibedakan menjadi 3 kategori, yaitu diploma, S1, dan S2. Komposisi responden berdasarkan penelitian terakhir responden adalah sebagai berikut:

Komposisi Pendidikan Terakhir Responden

\begin{tabular}{|c|l|c|c|}
\hline No. & $\begin{array}{c}\text { Pendidikan } \\
\text { Terakhir }\end{array}$ & $\begin{array}{c}\text { Jumlah } \\
\text { Responden }\end{array}$ & Persentase \\
\hline 1 & Diploma & 22 & 44 \\
\hline 2 & S1 & 24 & 48 \\
\hline 3 & S2 & 4 & 8 \\
\hline & Total & 50 & 100 \\
\hline
\end{tabular}




\section{Uji Statistik Deskriptif}

Hasil Uji Statistik Deskriptif

Descriptive Statistic

\begin{tabular}{|c|c|c|c|c|c|}
\hline & $\mathrm{N}$ & Minimum & Maximum & Mean & $\begin{array}{c}\text { Std. } \\
\text { Deviation }\end{array}$ \\
\hline Pengendalian Internal & 50 & 43 & 70 & 56.54 & 5.482 \\
Komitmen Organisasi & 50 & 28 & 45 & 36.48 & 3.564 \\
Pencegahan Fraud & 50 & 9 & 20 & 13.34 & 3.041 \\
Pengadaan Barang & 50 & & & & \\
Valid N (listwise) & & & & \\
\hline
\end{tabular}

Dari Tabel 4 dijelaskan bahwa jumlah data (N) yang diuji sebanyak 50. Selain itu diperoleh gambaran nilai minimum, maximum, mean, dan standar deviasi masing-masing variabel. Variabel pengendalian internal nilai minimum 43 , maximum 70 , mean 56,54 dan standar deviasi 5,482. Variabel komitmen organisasi nilai minimum 28 , maximum 45 , mean 36,48 dan standar deviasi 3,564. Variabel pencegahan fraud pengadaan barang nilai minimum 9, maximum 20, mean 13,34 dan standar deviasi 3,041 .

\section{Uji Hipotesis}

Tabel 5. Hasil Uji F

ANOVA $^{\mathrm{a}}$

\begin{tabular}{|c|c|c|c|c|c|c|}
\hline \multicolumn{2}{|c|}{ Model } & \multirow{2}{*}{\begin{tabular}{|c|}
$\begin{array}{l}\text { Sum of } \\
\text { Squares }\end{array}$ \\
24.763 \\
\end{tabular}} & \multirow{2}{*}{ Df } & \multirow{2}{*}{\begin{tabular}{|r|} 
Mean Square \\
127.381 \\
\end{tabular}} & \multirow{2}{*}{$\frac{F}{4.358}$} & \multirow{2}{*}{$\frac{\text { Sig. }}{.027^{\mathrm{a}}}$} \\
\hline 1 & Regression & & & & & \\
\hline & Residual & 428.457 & 47 & 9.116 & & \\
\hline & Total & 453.220 & 49 & & & \\
\hline
\end{tabular}

a. Predictors: (Constant), Pengendalian internal, Komitmen organisasi

b. Dependent Variable: Pencegahan fraud pengadaan

barang

Tabel 5 menunjukkan hasil uji $\mathrm{F}$ sebesar 4,358 dengan tingkat signifikansi 0,027. Karena nilai probabilitas 0,027 lebih kecil dari 0,05 dapat dikatakan bahwa pengendalian internal dan komitmen organisasi secara bersama-sama mempengaruhi variabel pencegahan fraud pengadaan barang.

\section{Hasil Uji t}

Coefficients $^{\mathrm{a}}$

\begin{tabular}{|l|r|r|c|r|r|}
\hline \multirow{2}{*}{ Model } & \multicolumn{2}{|c|}{$\begin{array}{c}\text { Unstandardized } \\
\text { Coefficients }\end{array}$} & $\begin{array}{c}\text { Standardized } \\
\text { Coefficients }\end{array}$ & & \\
\cline { 2 - 5 } & \multicolumn{1}{|c|}{$\mathrm{B}$} & Std. Error & \multicolumn{1}{|c|}{ Beta } & \multicolumn{1}{c|}{$\mathrm{T}$} & Sig. \\
\hline 1 (Constant) & 6.264 & 6.104 & & 1.026 & .310 \\
Pengendalian Internal & .130 & .079 & .234 & 1.648 & .016 \\
Komitmen Organisasi & .107 & .121 & .099 & .891 & .032 \\
\hline
\end{tabular}

a. Dependent Variable: Pencegahan Fraud Pengadaan Barang

Berdasarkan hasil uji diatas, maka:

a. Variabel pengendalian internal memiliki t hitung sebesar 1,648 dengan taraf signifikan 0,016 dibawah signifikansi 0,05 (5\%). Dengan demikian $\mathrm{t}$ hitung $>\mathrm{t}$ tabel atau 1,648 $>0,016$. Karena itu, dapat 
disimpulkan bahwa pengendalian internal secara parsial berpengaruh terhadap pencegahan fraud pengadaan barang. Hasil ini membuktikan bahwa hipotesis $\mathrm{H} 1$ diterima.

b. Variabel komitmen organisasi memiliki t hitung 0,891 dengan taraf signifikansi 0,032 dibawah signifikansi 0,05 (5\%). Dengan demikian t hitung > t tabel atau 0,891>0,679. Karena itu, dapat disimpulkan bahwa komitmen organisasi secara parsial berpengaruh terhadap pencegahan fraud pengadaan barang. Hasil ini membuktikan bahwa hipotesis $\mathrm{H} 2$ diterima.

\section{KESIMPULAN}

Berdasarkan uraian diatas dan hasil analisis yang telah dijabarkan tentang Pengaruh pengendalian internal dan komitmen organisasi terhadap pencegahan fraud pengadaan barang dapat ditarik kesimpulan sebagai berikut:

1. Pengendalian Internal secara signifikan berpengaruh positif terhadap Pencegahan Fraud Pengadaan Barang pada Rumah Sakit Pemerintah Kota Ambon. Dengan demikian, diharapkan pencegahan fraud pengadaan barang dapat meningkat dengan diterapkannya pengendalian internal yang baik pada rumah sakit pemerintah.

2. Komitmen Organisasi secara signifikan berpengaruh positif terhadap Pencegahan Fraud Pengadaan Barang pada Rumah Sakit Pemerintah Kota Ambon. Jadi semakin baik Komitmen Organisasi yang ditanamkan dalam diri masing-masing karyawan, maka akan semakin meningkatnya pencegahan fraud pengadaan barang yang mungkin dilakukan oleh diri sendiri (karyawan).

\section{DAFTAR PUSTAKA}

Boynton, W. C., Johnson, R. N. dan Walter, G. K. (1996)., Modern Auditing, $6^{\text {th }}$ Edition, New York: John Wiley 7 Sons, Inc.

Hermiyetti. (2010)., Penerapan Pengendalian Internal terhadap Pencegahan Kecurangan Pengadaan Barang. Jurnal Akuntansi dan Auditing Indonesia, Vol. 14, No. 2.

Meyer, J dan Allen, N. (1997)., Testing the "Side Bet Theory" of Organizational Commitment: Some Methodological Considerations, Journal of Applied Psychology, 69:372-378.

Mowday, R. T., Porter, L.M. dan Steers, R. (1979)., The meansurement of organizational commitment. San Diego: Academic Press.

Mulyadi. (2002)., Auditing, Buku 1, Edisi Enam, Jakarta: Salemba Empat.

Pikiran-rakyat.com. Pengadaan alat kesehatan paling banyak jadi objek Korupsi. Diakses pada tanggal 17 Januari 2019.

Pope, J. (2007)., Strategi Memberantas Korupsi: Elemen Sistem Integritas Nasional, Edisi II, Jakarta: Yayasan Obor Indonesia.

Tuanakotta, T. M. (2007)., Akuntansi Forensik dan Audit Investigatif. Jakarta: Lembaga Penerbit Fakultas Ekonomi Universitas Indonesia (LPFE UI).

Wilopo. (2006)., Analisis Faktor-faktor yang Berpengeruh terhadap Kecenderungan Kecurangan Akuntansi: Studi pada Perusahaann Publik dan Badan Usaha Milik Negara di Indonesia. Simposium Nasional Akuntansi (SNA 9) Padang.

Zulkarnain, R.M. (2013)., Analisis Faktor Yang Mempengaruhi Terjadinya Fraud Pada Dinas Kota Surakarta. Accounting Analysis Journal. Universitas Negeri Semarang. 